\title{
ПАТОЛОГО-АНАТОМИЧЕСКИЕ ИЗМЕНЕНИЯ У КУР-НЕСУШЕК ПРИ АСКАРИДИОЗЕ
}

\section{T.I. Vakhrusheva}

\section{PATHOLOGICAL AND ANATOMATICAL CHANGES IN LAYING HENS HAVING ASCARADIOSIS}

Вахрушева Татьяна Ивановна - канд. ветеринар. наук, доц. каф. анатомии, патологической анатомии и хирургии Красноярского государственного аграрного университета, г. Красноярск. E-mail: vlad_77.07@mail.ru

Изучена патоморфологическая картина изменений органов и тканей павших и вынужденно убитых кур-несушек с клиническими признаками инвазии нематодами Ascaridia galli, ycmaновлены характерные патогномоничные для основного заболевания макро- и микроскопические изменения, а также развившиеся на их фоне осложнения и причинно-следственная связь между ним. Проведена дирореренциальная диагностика основных осложнений от инфекционных болезней со сходными клиникоморфологическими признаками. Объектами исследования являлись куры-несушки, содержащиеся в одном из приусадебных хозяйств, расположенном на территории Емельяновского района Красноярского края. В течение 2019 г. было проведено патолого-анатомическое вскрытие 12 трупов птии. В ходе исследования проводился забор материала для гистологического исследования - фрагменты тканей тонкого и толстого отделов кишечника, поджелудочной железы, печени, почек, селезенки, сердца, яичника и яйцевода, срезы изготавливались на микротоме "Техном МЗП-01», окрашивались гематоксилином Эрлиха и эозином. Для проведения диффференциальной диагностики в лабораторию отправлялся патологоанатомический материал, инфрекция была исключена во всех случаях. Результаты изучения органов и тканей показали, что причиной гибели птиц стала инвазия нематодами Ascaridia galli. Ведущую роль в развитии глубоких метаболических процессов, полиорганной недостаточности и кахексии, обуславливающих летальный исход, играли непосредственное ме-
Vakhrusheva Tatyana Ivanovna - Cand. Veterinary Sci., Assoc. Prof., Chair of Anatomy, Pathological Anatomy and Surgery, Krasnoyarsk State Agrarian University, Krasnoyarsk.

E-mail: vlad_77.07@mail.ru

ханическое повреждение паразитами структур слизистой оболочки кишечной стенки в сочетании с токсическим влиянием продуктов жизнедеятельности паразитов и аллергической перестройкой организма птицы. Полученные данные расширяют представление о патогенезе заболевания и изменениях в различных органах и тканях, что позволит оптимизировать применяемые методы и способы лечения с целью повышения их эфффективности.

Ключевые слова: куры-несушки, инвазия, нематоды, аскаридиоз кур, болезни птицы, Ascaridia galli.

Pathological and morphological picture of the organs and tissues of dead and involuntarily killed chickens with clinical signs of Ascaridia galli nematodes invasion was studied, macro- and microscopic pathognomonic changes typical for the underlying disease, as well as complications and causal relationship between them that had developed on their background, were established. Differential diagnosis of the main complications from infectious diseases with similar clinical and morphological signs was carried out. The objects of the study were laying hens kept in one of the household farms located on the territory of Emelyanovsky district, Krasnoyarsk Region. During 2019 the postmortem autopsy of 12 corpses of the birds was performed. During the study the material was collected for histological examination - tissue fragments of small and large intestines, pancreas, liver, kidneys, spleen, heart, ovary, oviduct, sections which were made on Technom MZP-01 microtome, stained with Ehrlich hematoxylin and eosin. For differential 
diagnosis pathological material was sent to the laboratory, the infection was excluded in all the cases. The results of the study of organs and tissues showed that the invasion of Ascaridia galli nematodes became the cause of the birds' death. Leading role in the development of deep metabolic processes, multiple organ failure and cachexia, causing fatal outcome was played by direct mechanical damage of the structures of the mucous membrane of intestinal wall caused by the parasites in combination with toxic effect of the parasite' waste products of and allergic reorganization of the bird's body. The data obtained expand the understanding of the pathogenesis of the disease and changes in various organs and tissues, which will optimize the methods and ways of treatment used to increase their effectiveness.

Keywords: laying hens, invasion, nematodes, ascariasis of chickens, poultry diseases, Ascaridia galli.

Введение. Серьезным препятствием на пути повышения продуктивности сельскохозяйственной птицы являются инвазионные болезни, из которых наиболее опасные - гельминтозы, часто имеющие хроническое течение. Заболевание приводит к значительным экономическим потерям за счет снижения привесов, яйценоскости кур, ухудшения качества получаемой продукции. Кроме того, паразиты вызывают снижение иммунной реактивности организма, что способствует развитию осложнений воспалительными процессами различных органов и тканей, а также отрицательно влияет на напряженность поствакцинального иммунитета [1-3].

Аскаридиоз кур повсеместно встречается на территории Российской Федерации, однако экстенсивность и интенсивность инвазии зависят главным образом от условий содержания и кормления птиц. Технология напольновыгульного содержания кур создает условия для заражения их в результате постоянного и продолжительного трофического контакта с инвазионным началом, при этом в полости кишечника птицы наблюдается максимальное накопление паразитов, находящихся на разных стадиях развития. По данным различных исследователей, экстенсивность инвазии нематодами Ascaridia galli у взрослых кур в приусадебных хозяйствах колеблется от 32,7 до 82,0 \% [3, 4].
Клинические признаки при аскаридиозе у кур зависят от возраста, интенсивности заражения, кормления и условий содержания. При слабой степени инвазии, чаще у взрослых особей, аскаридиоз протекает без выраженных симптомов, у цыплят в основном наблюдается интенсивная степень инвазии, заканчивающаяся летальным исходом [1, 4-6].

При значительной степени заражения у больной аскаридиозом птицы наблюдаются следующие клинические симптомы: вялость, отсутствие аппетита, диарея, выраженное снижение живой массы, задержка развития скелетной мускулатуры и костей скелета, а также резкое уменьшение яйценоскости. При клиническом осмотре выявляются такие изменения, как взъерошенность, сухость и ломкость перьевого покрова, анемия и цианоз производных кожных покровов в области головы - сережек, бородок и гребня, а также видимых слизистых оболочек. При исследовании гематологических показателей в крови больных птиц наблюдается выраженное снижение содержания гемоглобина и количества эритроцитов, а также увеличение количества лейкоцитов и эозинофилов, при остром течении инвазии отмечается уменьшение содержания Т-лимфоцитов, при хроническом уменьшается также количество В-лимфоцитов, снижается фрагоцитарная активность сыворотки крови и ее комплементарной активности, а также уровня лизоцима, при этом отмечается возрастание количества общего белка сыворотки крови, а в соотношении белковых фрракций происходит уменьшение количества альбуминов и увеличение глобулинов [1, 4-9].

Прижизненная и посмертная диагностика аскаридиозов у птиц не вызывает особых затруднений и основывается на обнаружении паразитов на различных стадиях развития и их яиц в полости кишечника и каловых массах посредством гельминто-копрологических исследований и копрологических вскрытий, однако вследствие резкого снижения резистентности организма инвазия может быть осложнена какими-либо инфекционными болезнями, в этой связи изучение патоморфологических изменений органов и тканей при аскаридиозе у кур и их дифференциальная диагностика представляют особый научный и практический интерес [2]. 
Цель исследования. Анализ патологоанатомических изменений у кур-несушек при инвазии нематодами Ascaridia galli с установлением основного заболевания, его осложнений и причинно-следственных связей между ними.

Материалы и методы исследования. Объектом исследования являлись куры-несушки, содержащиеся в одном из приусадебных хозяйств Емельяновского района Красноярского края. В течение 2019 г. было проведено патолого-анатомическое вскрытие 12 трупов кур породы Леггорн белый, из которых 6 голов павших и 6 вынужденно убитых в возрасте от 10 месяцев до 1,3 лет. Во время вскрытия проводился забор материала для гистологического исследования - фррагменты тканей тонкого и толстого отделов кишечника, поджелудочной железы, печени, почек, селезенки, сердца, яичника и яйцевода. Патолого-анатомический материал фиксировался в 10\%-м нейтральном растворе формалина, срезы изготавливались на микротоме «Техном МЗП-01», окрашивались гематоксилином Эрлиха и эозином, микроскопия проводилась на микроскопе «Levenhuk 320». Микрофотосъемку и анализ микрофотографий проводили на фотоаппарате Canon EOS 1100D. Bидовую принадлежность обнаруженных в полости кишечника кур паразитов определяли органолептическим методом.

Для проведения дифференциальной диагностики в лабораторию отправлялся патолого- анатомический материал - фрагмент кишечника, кусочки легких, селезенки, печени, почек, поджелудочной железы - специфическая инфекция была исключена во всех случаях.

Результаты исследования и их обсуждение. У всех птиц при жизни наблюдались следующие клинические признаки: вялость, отсутствие аппетита, резкое снижение яйценоскости, бледность и синюшность производных кожи в области головы, взъерошенность и тусклость перьевого покрова, уменьшение живой массы, диарея с примесью слизи и крови. Проявление симптомов болезни ослаблялось после применения курсов антибиотиков (Энрофрлоксацин, 10 \%), через 1421-е сутки проявление клинических признаков болезни возобновлялось.

При патоморфологическом исследовании всех трупов птиц выявлялись признаки анемии, кахексии, общей застойной гиперемии (рис. 1). Изменения органов пищеварительной системы характеризовались следующей картиной: во всех случаях патолого-анатомического вскрытия наблюдалась картина острого катарального или серозно-катарального гастрита железистого отдела, а также острого и подострого серозного воспаления слизистой и кутикулы мускульного отдела желудка (рис. 2). У 67 \% птиц также выявлялись множественные точечные и мелкопятнистые диапедезные кровоизлияния в слизистой и кутикуле (рис. 2).

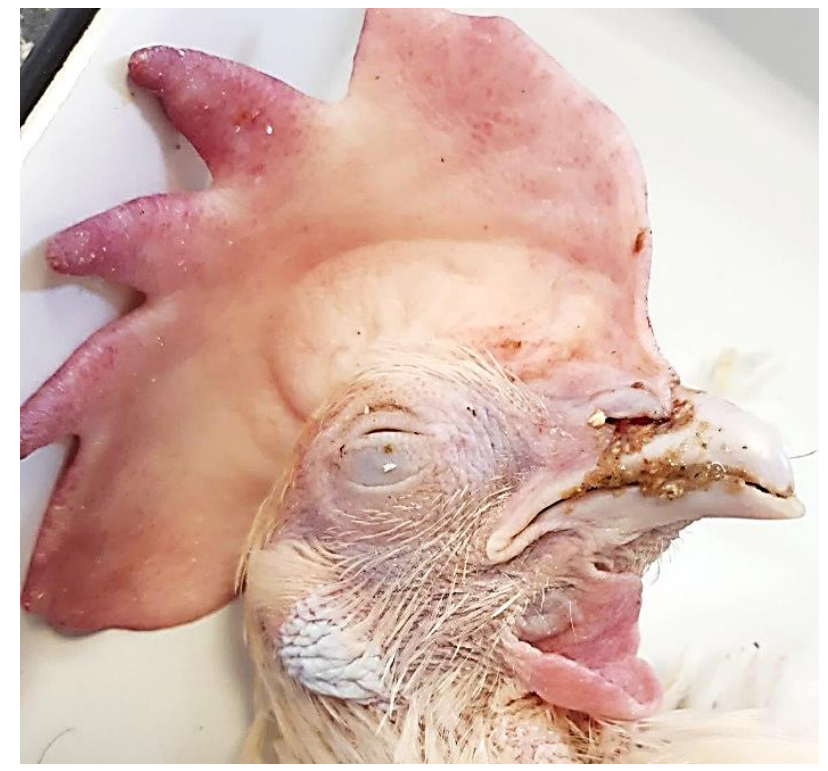

Puc. 1. Анемия и цианоз тканей гребня и бородок курицы 


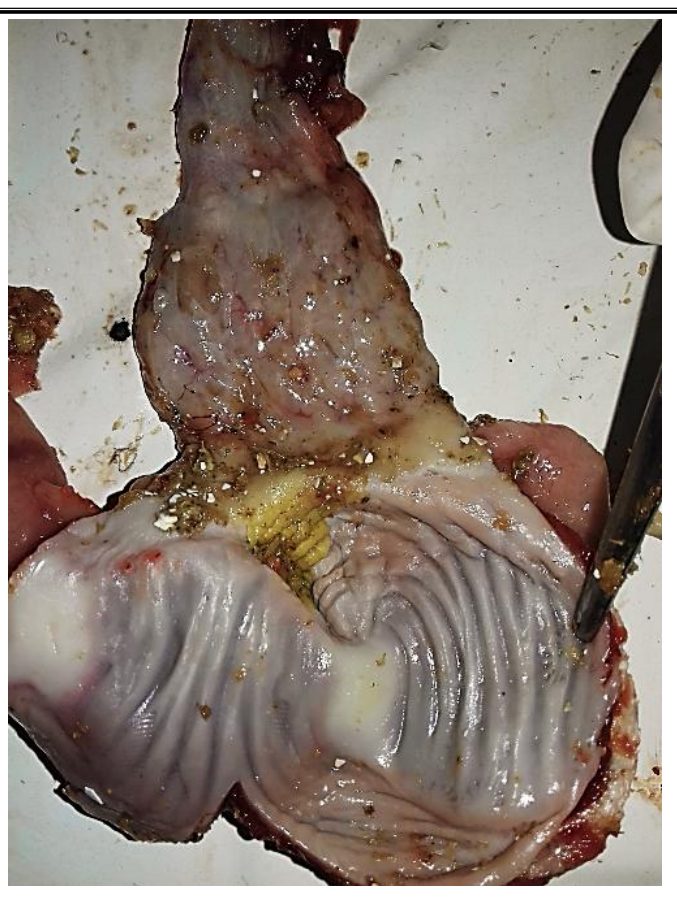

Рис. 2. Желудок курицы: острый катаральный гастрит, кровоизлияния

При исследовании кишечника выявлялось, что основные изменения локализовались в тонком отделе - двенадцатиперстной и тощей кишках и характеризовались наличием в полости значительного количества гельминтов, имеющих следующую морфологию: тело - цилиндрической формы, полупрозрачное, бело-желтого цвета, длина паразитов составляла от 3,0 до 12,2 см в количестве от 12 до 34 особей. Видовая пренадлежность паразитов была определе- на как нематода Ascaridia galli, семейство Ascaridae. B 50 \% случаев вскрытия отмечалась частичная или полная обтурация просвета кишечника паразитами (рис. 3), обуславливая состояние полной или частичной непроходимости кишечника. Также выявлялось развитие острого воспалительного процесса слизистой кишечника у 83,33 \% птиц обнаруживались признаки серознокатарального, у $17 \%$ - острого катаральногеморрагического эрозивного энтерита (рис. 4).

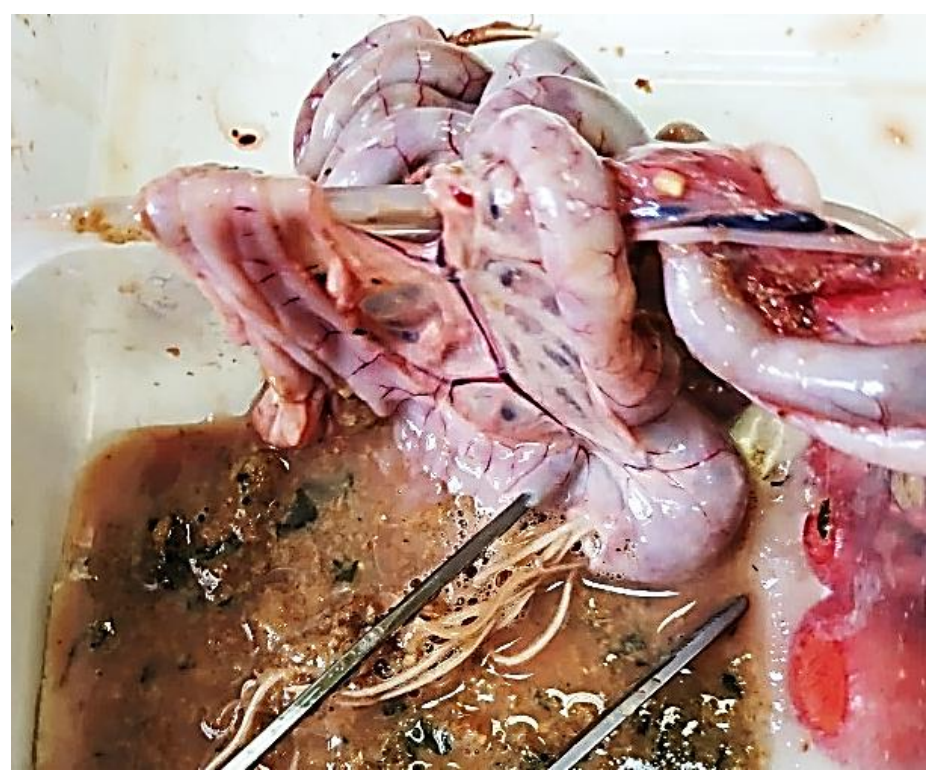

Puс. 3. Расширение полости и обтурация просвета тощей кишки курицы аскаридиями 


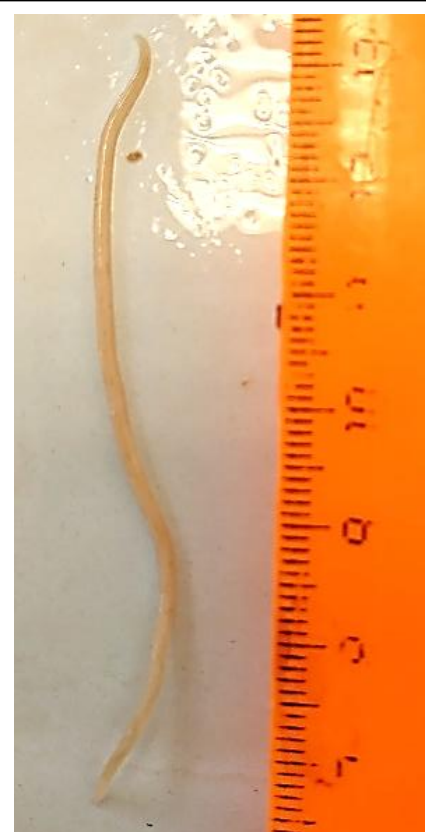

Puc. 4. Нематода Ascaridia galli, извлеченная из полости тощей кишки курицы (длина 72,00 мм)

Просвет кишечника большинства кур - значительно расширен, в том числе из-за снижения мышечного тонуса, серозные покровы - интенсивно покрасневшие, сосуды - повышенно кровенаполнены, слизистая утолщена, отечная, покрыта обильным количеством непрозрачной слизи, в толще слизистой у всех исследуемых трупов выявлялись очаги точечных диапедезных кровоизлияний, имеющих тенденцию к слиянию и формирующих картину геморрагической пурпуры, на месте которых отмечались неглубокие десекты слизистой с неровными краями и буро-красного цвета дном (рис. 5,6 ).

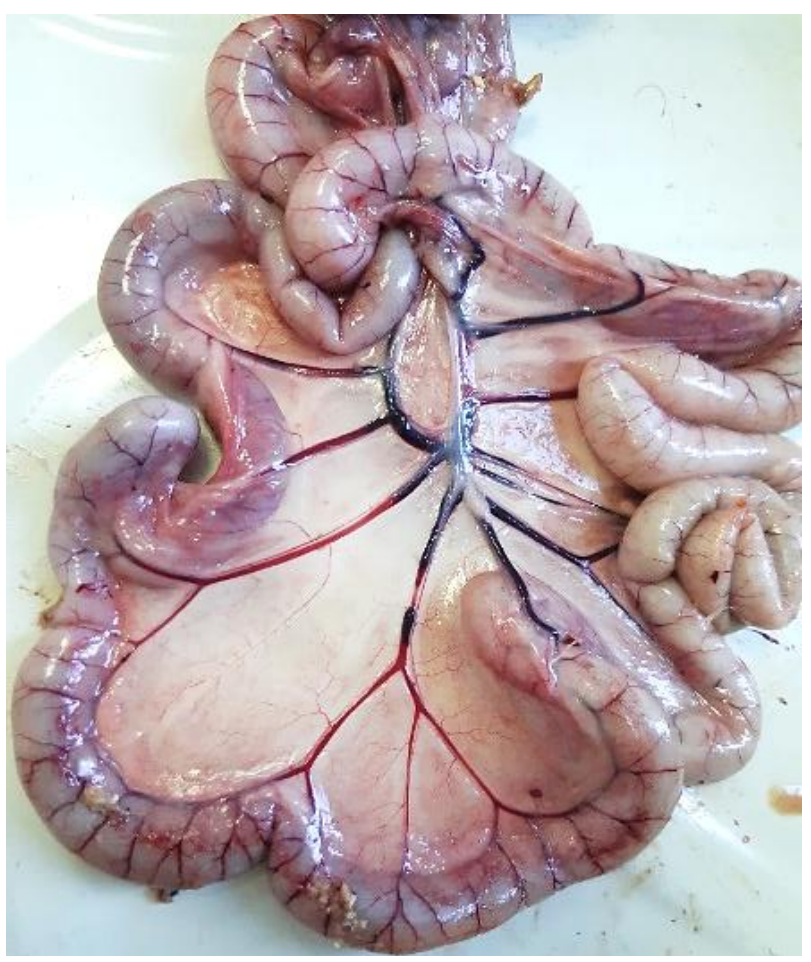

Puc. 5. Расширение просвета тощей кишки курищы, острая гиперемия сосудов 


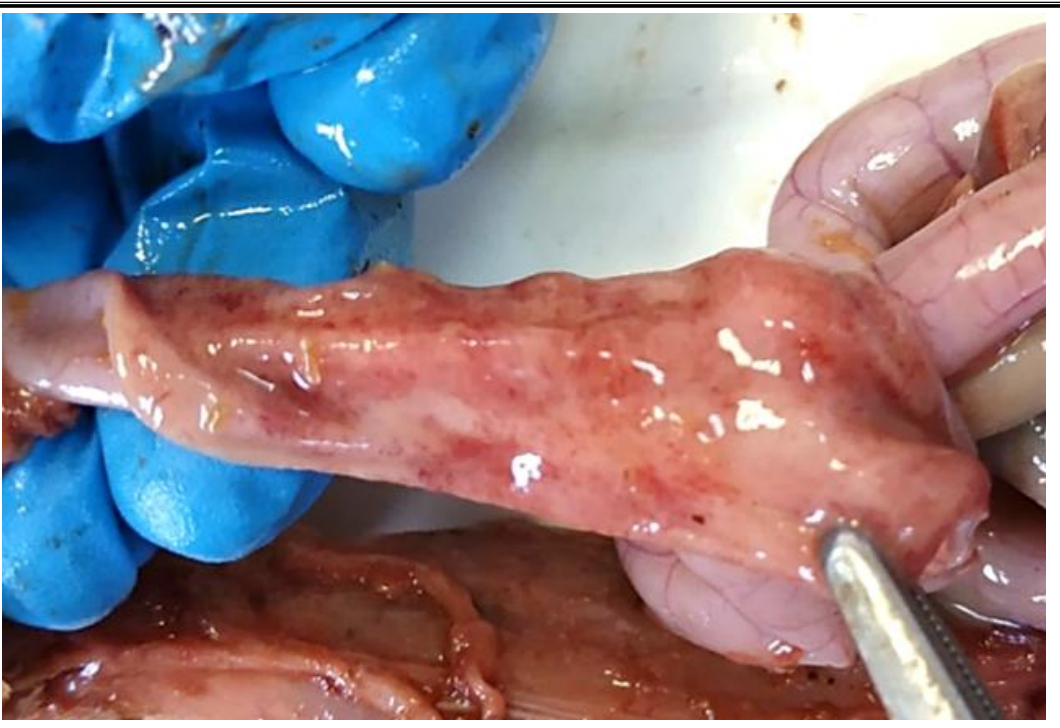

Puc. 6. Острый серозно-катаральный еюнит, кровоизлияния на слизистой тощей кишки курищы

При гистологическом исследовании выявлялась картина острого катаральнодесквамативного или катаральногеморрагического некротизирующего воспаления тонкого отдела кишечника, характеризующаяся нарушением структуры, десормацией, истончением и адгезией микроворсинок, а также глубокой слизистой дистрофией, тотальным некрозом и десквамацией энтероцитов ворсинок и крипт, с полной или частичной утратой кишеч- ных эндокриноцитов, которые сохранялись только лишь среди эпителиальных клеток крипт, также наблюдалось наличие мелких кровоизлияний, особенно в апикальных участках ворсинок, в сочетании с очаговой гиперплазией железистого эпителия крипт (рис. 7). В собственной пластине слизистой ворсинок наблюдалась воспалительная гиперемия сосудов и выраженный периваскулярный отек (рис. 8).

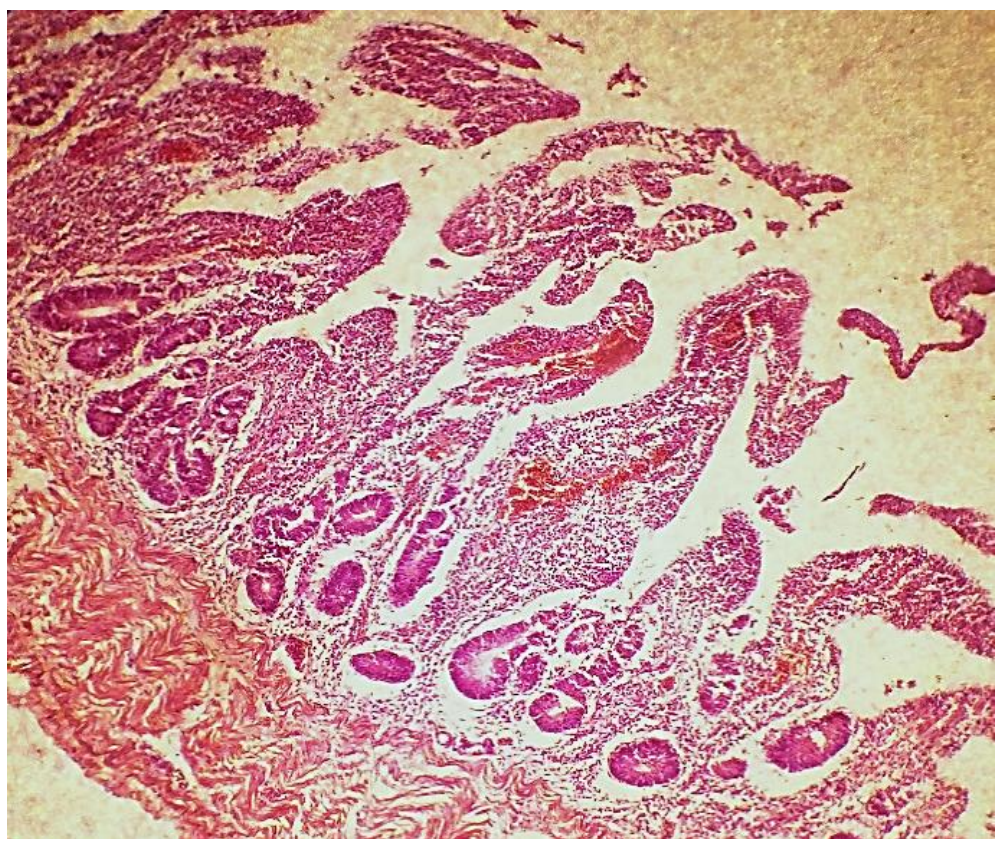

Puc. 7. Острый десквамативный катар слизистой тощей кишки курищы, деформация и атрофрия микроворсинок (окраска гематоксилином и эозином × 100) 


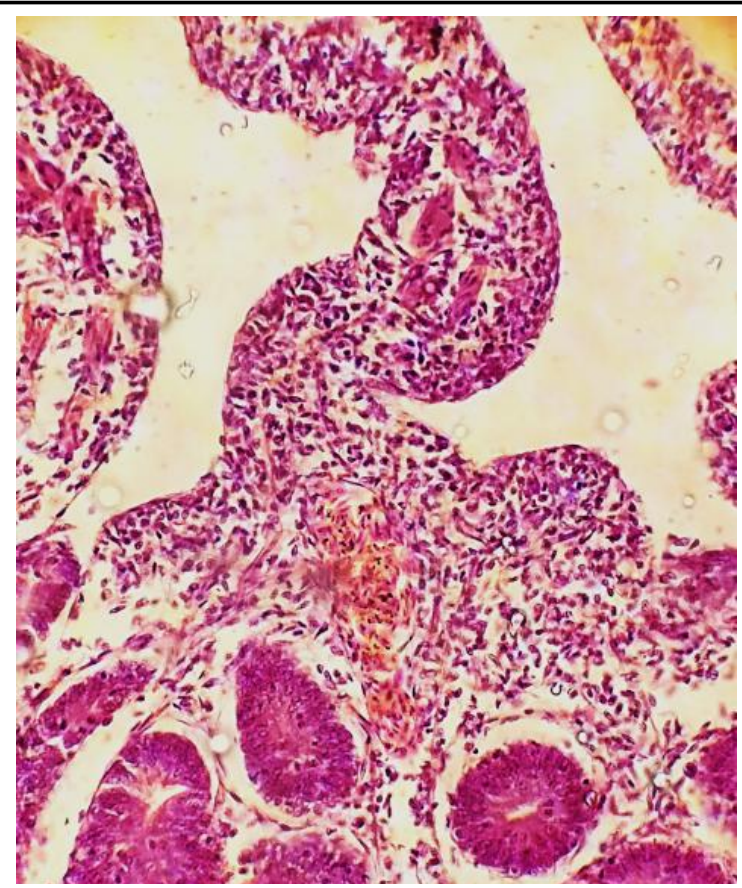

Puc. 8. Тотальный некроз эпителиоцитов и воспалительная гиперемия микроворсинок кишечника (окраска гематоксилином и эозином × 400)

В толстом отделе кишечника во всех случаях кой консистенции с примесью слизи, при этом вскрытия (100 \%) наблюдались признаки остро- аскаридии в слепых и прямой кишках не обнаго катара - слизистая утолщена, покрыта значи- руживались (рис. 9). Полость клоаки - расширетельным количеством непрозрачной слизи, в на, слизистая - с признаками острого катара, полости кишечника - значительное количество утолщена, набухшая, ярко-красного цвета, с каловых масс желто-зеленого цвета, полужид- кровоизлияниями (рис. 10).

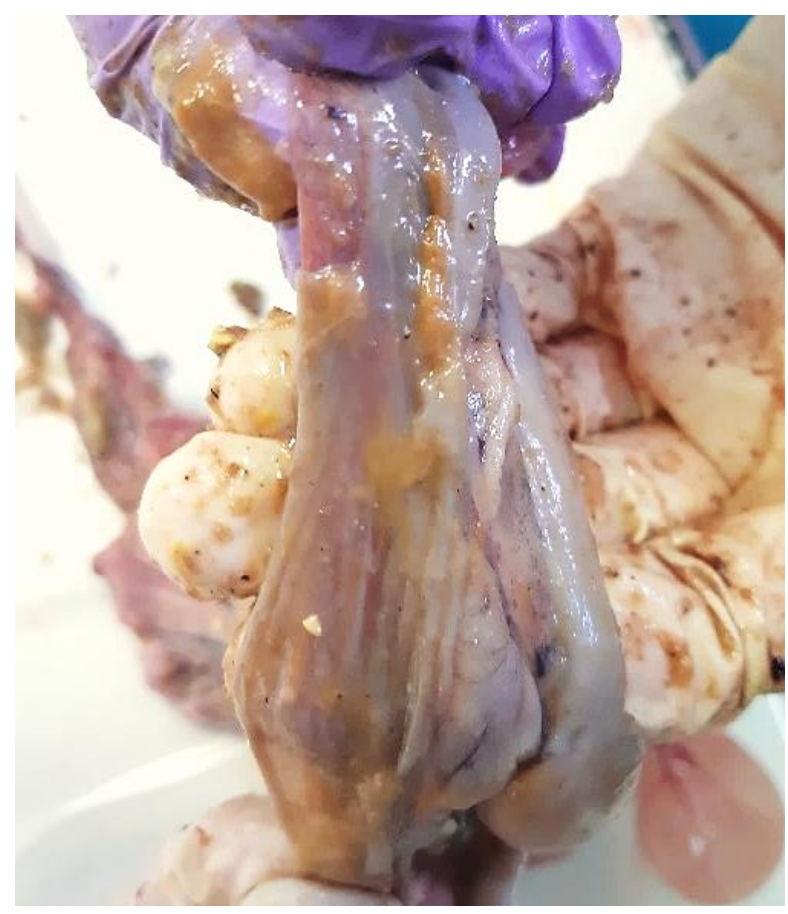

Рuс. 9. Острый катар слизистой прямой кишки курищы 


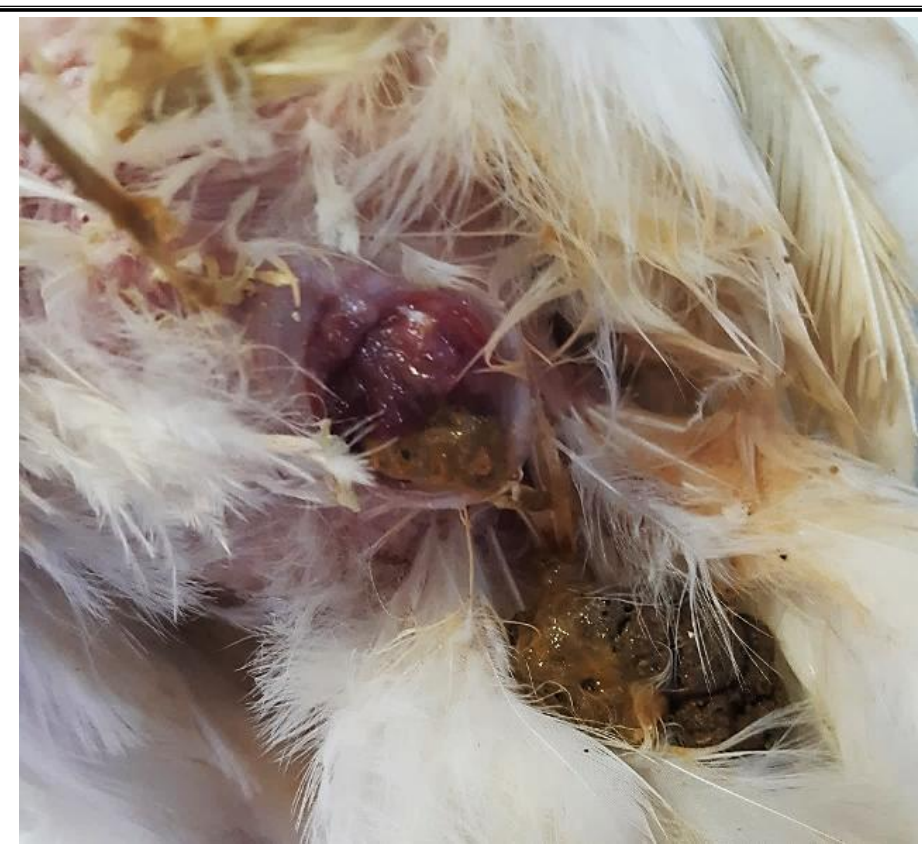

Рuс. 10. Острый катаральный клоацит

Патоморфологические изменения печени у всех птиц характеризовались признаками острой застойной гиперемии, а также диффузной и очаговой белково-жировой дистрофией различной степени выраженности - в $75 \%$ случаев умеренной, в $25 \%$ - глубокой дегенерацией (рис. 11).

При микроскопическом исследовании наблюдалось нарушение балочного строения долек, выраженное диффузное полнокровие вен портальных трактов, центральных вен и сунусоидных капилляров, отек периваскулярной ткани и перисинусоидальных пространств, гепатоциты увеличены, деформированы, в цитоплазме наблюдается наличие мелкой ацидофильной зернистости и множественных жировых капель, которые зачастую заполняют все пространство клетки, ядра клеток располагаются центрально, многие в состоянии пикноза (рис. 12).

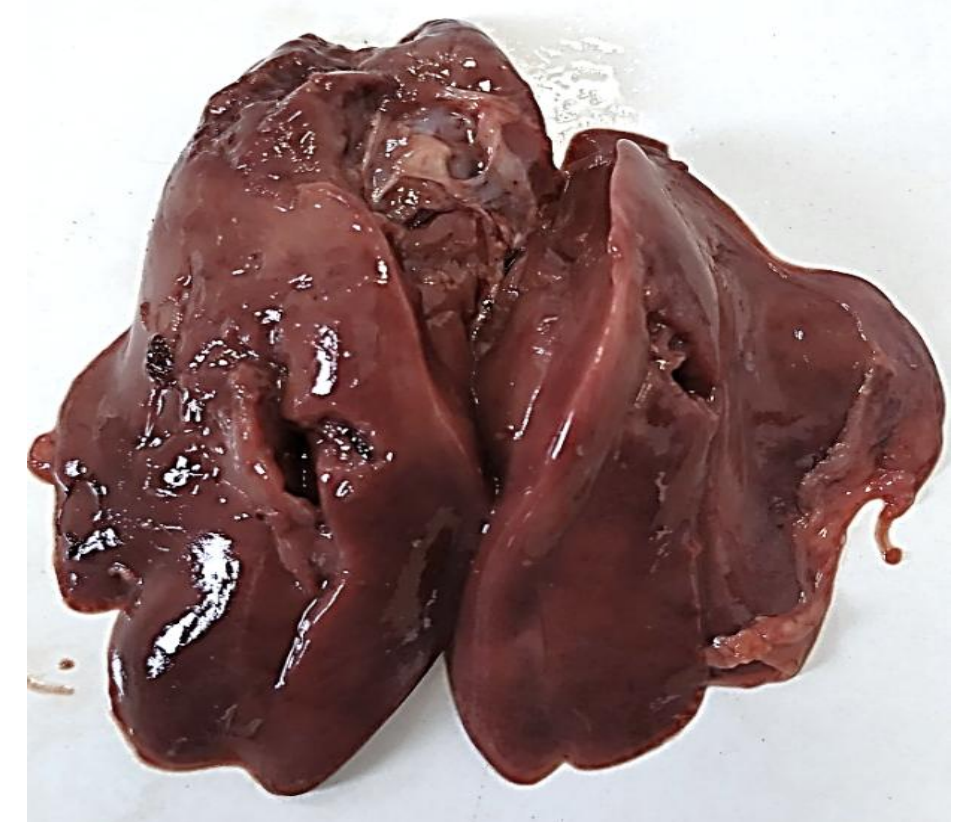

Puc. 11. Острая застойная гиперемия и зернисто-жировая дистрофрия печени курицы 


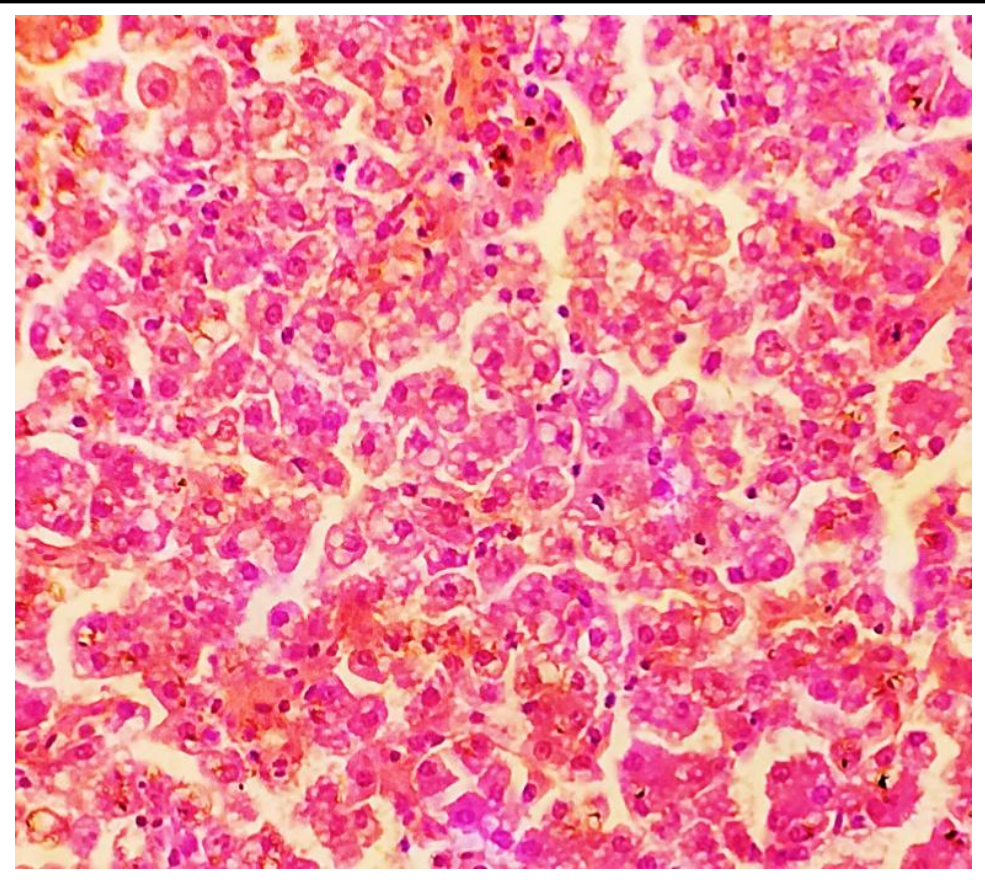

Puc. 12. Застойная гиперемия синусоидных капилляров и очаг дегенеративного ожирения печени (окраска гематоксилином и эозином × 400)

При исследовании патоморфологических изменений поджелудочной железы у 83,3 \% исследуемых птиц выявлялись выраженные признаки острого серозного отека, а также мелкий красный крап под капсулой и в паренхиме, который при гистологическом исследовании соответствовал локализации повышенно инъецированных сосудов и кровоизлияний (рис. 13). Микроскопически в тканях органа обнаруживалось острое дифффузное венозно-капиллярное полнокровие с эритростазами, утолщение стенок крупных сосудов вследствие плазматического их пропитывания и мукоидного набухания, серозный отек стромы органа, при этом строение железистой ткани не было нарушено, островки Лангерганса обнаруживались на площади срезов в незначительном количестве, с признаками острого серозного отека стромы. У $25 \%$ птиц в паренхиме органа выявлялись множественные диапедезные микрогеморрагии насыщеннокрасного цвета (рис. 14).

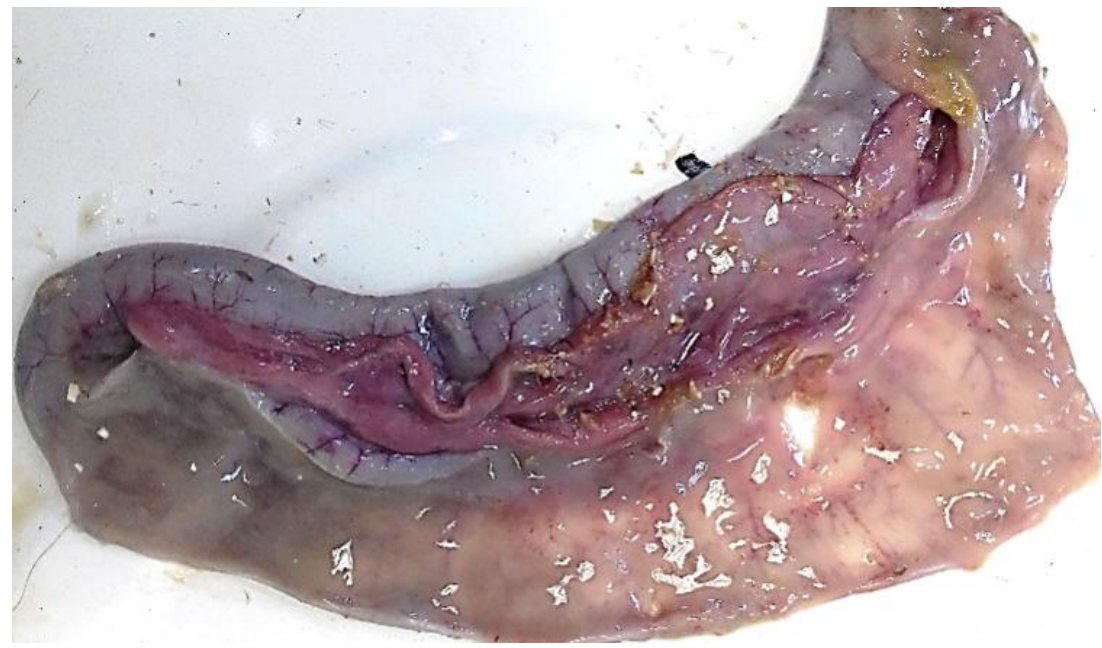

Puс. 13. Острый серозно-воспалительный отек поджелудочной железы курицы, острый серозно-катаральный дуоденит 


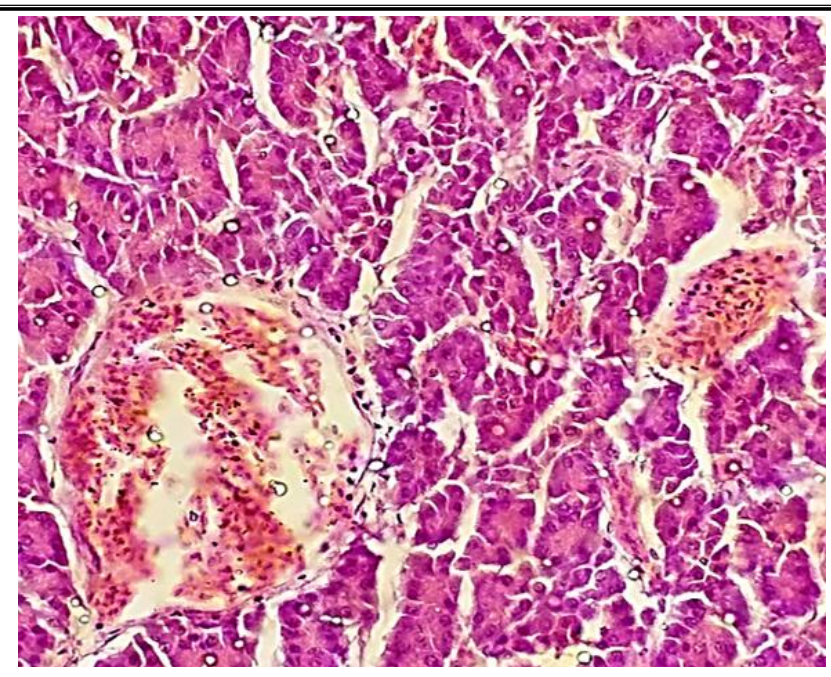

Puc. 14. Поджелудочная железа: острое венозно-капиллярное полнокровие, серозный отек стромы (окраска гематоксилином и эозином × 100)

При макроскопическом исследовании почек у всех птиц выявлялись признаки острой застойной гиперемии и белковой дистрофии различной степени выраженности, у 66,7 \% птиц в ткани органов на разрезе выявлялись скопления уратов в виде включений белого цвета мягкой мажущей консистенции (рис. 15). При гистологическом исследовании ткани почек выявлялось выраженное диффузное венозно-капиллярное полнокровие с эритростазами, интерстициальная ткань - в состоянии отека, особенно выраженного в периваскулярной области, стенки сосудов - утолщены за счет плазматического пропитывания. В клетках эпителия извитых каналь- цев, особенно проксимальных, выявлялись деструктивные процессы в виде мутного набухания, а также пикноза и лизиса ядер, в просветах большинства канальцев локализовались белковые цилиндры. Сосудистые клубочки почечных телец в состоянии мембранозного гломерулита, уменьшены в объеме, просветы капилляров сжаты, стенки капилляров неравномерно утолщены, ядра клеток эндотелия пикнотичны, полость капсулы клубочков - расширена, в состоянии отека, заполнена гомогенными бледнорозовыми массами, в некоторых почечных тельцах наблюдается набухание и отслоение внутреннего листка капсулы (рис. 16).

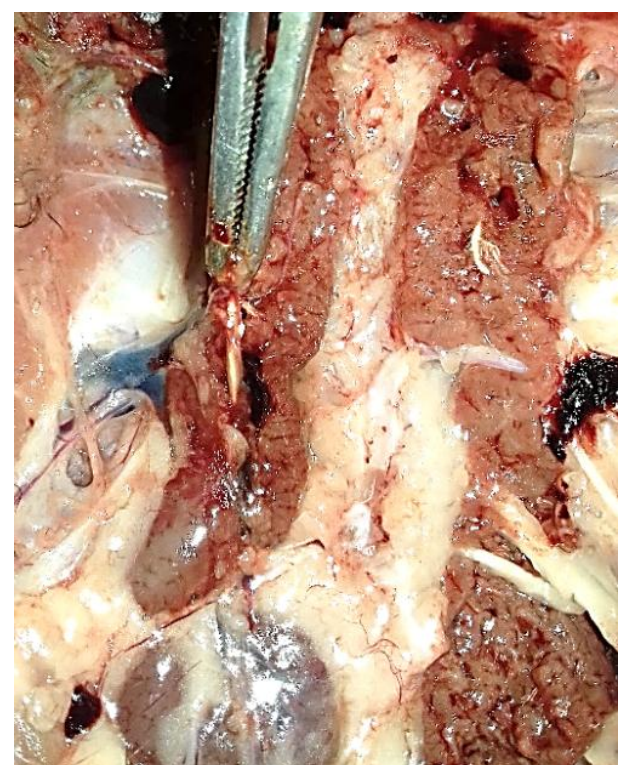

Puс. 15. Почки курищы: белковая дистрофия, скопление уратов 


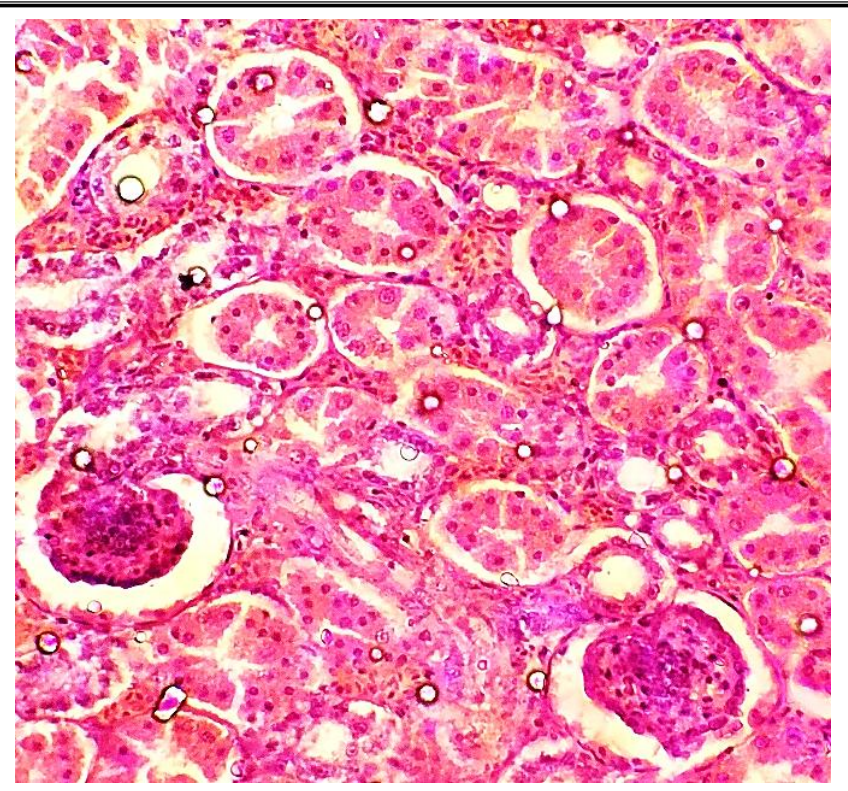

Puc. 16. Почки курищы: зернистая дистрофия эпителоцитов канальщев, мембранозньй гломерулит (окраска гематоксилином и эозином × 400)

При исследовании органов репродуктивной системы у всех исследуемых птиц выявлялись острые и подострые воспалительные процессы яичника и яйцевода серозно-катарального или геморрагического характера. Острый серозный овариит выявлялся у 67 \% кур, острый серозногеморрагический - у 33 \%, сальпингиты характеризовались поражением всех отделов яйцевода, при этом наиболее выраженные изменения наблюдались в белковом, скорлуповом и влагалищном отделах, с выпячиванием воспаленной части яйцевода через клоачное кольцо (рис. 17). При гистологическом исследовании обнаруживались признаки острого катарального или катарально-десквамативного катара тканей, характеризующиеся выраженной слизистой дистрофией, некрозом и десквамацией мерцательного эпителия складок, а также острым серозно-воспалительным отеком рыхлой соединительнотканной основы собственной пластики, подслизистого слоя и воспалительной гиперермией сосудов. В белковом отделе яйцевода отмечались выраженная дистрофия клеток и серозный отек белковых желез (рис. 18).

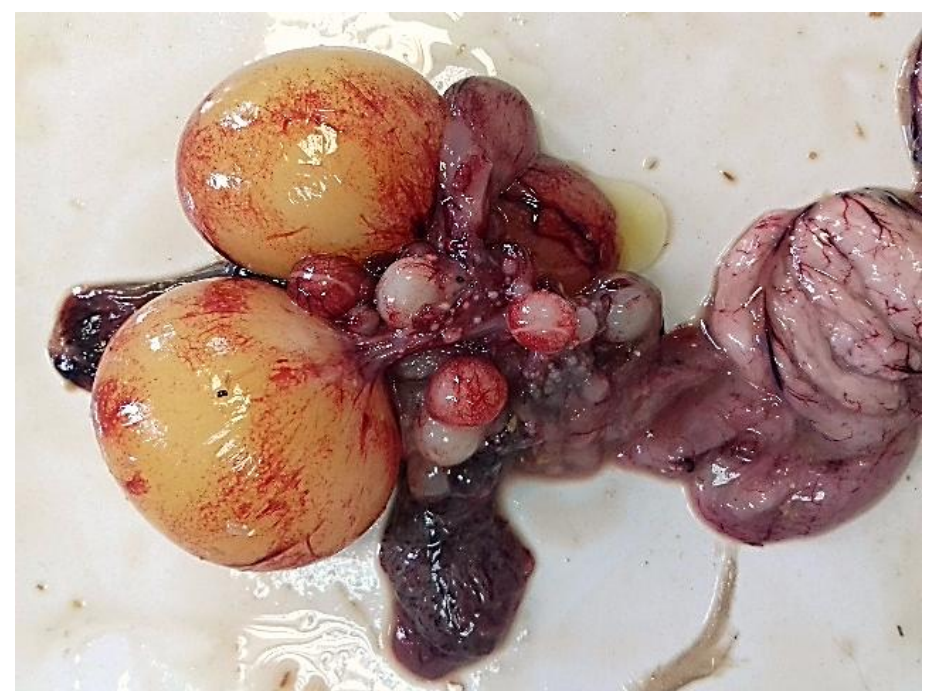

Puс. 17. Яичник курицы: острый серозно-геморрагический овариит, острый катарально-геморрагический сальпенгит 


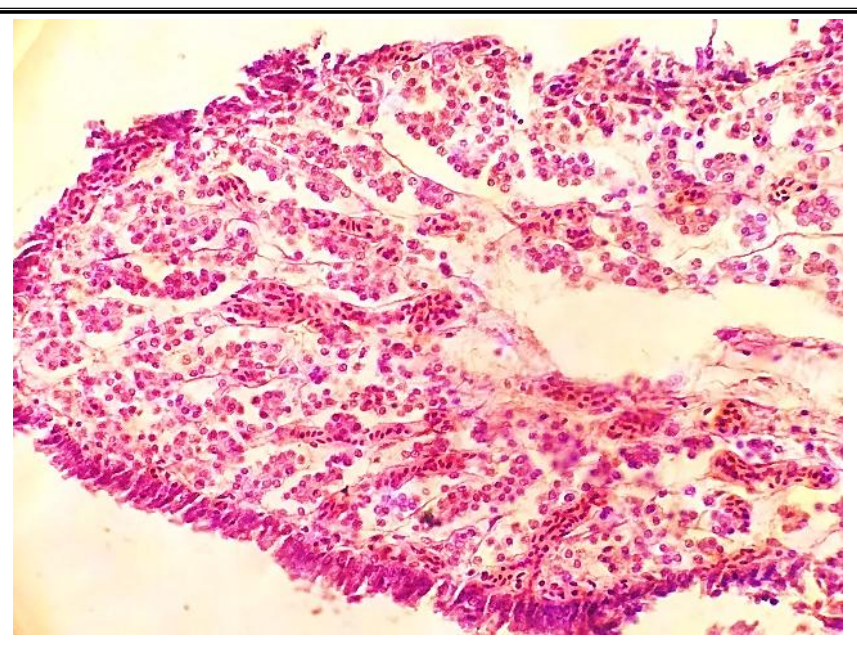

Puс. 18. Яйцевод курицы (скорлуповый отдел): острый десквамативный катар, серозный отек складок (окраска гематоксилином и эозином × 100)

Патоморфологические изменения селезенки у всех исследуемых трупов птиц соответствовали картине острой застойной гиперемии, у 50 \% выявлялись макроскопические признаки гиперплазии. Микроскопическая картина у $100 \%$ птиц соответствовала диффузно-очаговому венознокапиллярному полнокровию красной пульпы с наличием множественных диапедезных кровоизлияний и умеренного гемосидероза. У $75 \%$ птиц обнаруживались признаки атрофии лимфратических фролликулов, характеризующиеся резким уменьшением их линейных размеров, неправильной формой, отсутствием четких гра- ниц, умеренной делимфатизацией, также выявлялось утолщение стенок центральных артерий фолликулов вследствие плазматического пропитывания (рис. 19).

При исследовании тканей сердца у всех птиц выявлялась картина белковой дистрофии миокарда различной степени выраженности, микроскопически морфология изменений соответствовала зернистой дистрофии кардиомиоцитов, отмечалась их волнообразная деформация, гомогенизация саркоплазмы и пикноз ядер, а также серозный отек стромы и утолщение стенок сосудов вследствие мукоидного набухания (рис. 20).

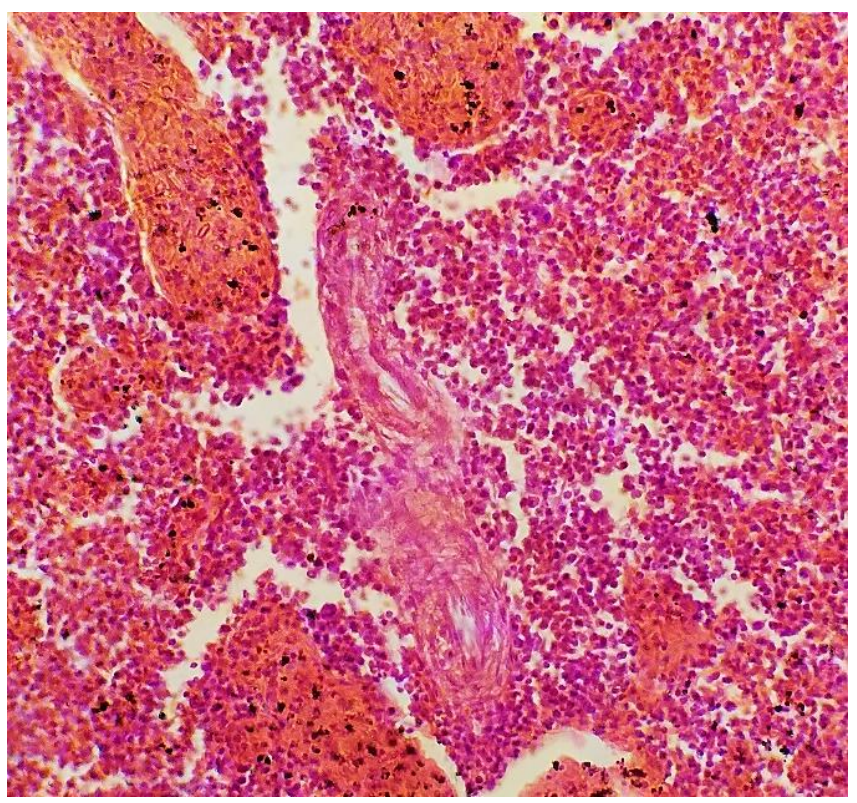

Puc. 19. Селезенка курицы: атрофия лифатического фолликула, гранулы гемосидерина в красной пульпе (окраска гематоксилином и эозином; × 400) 


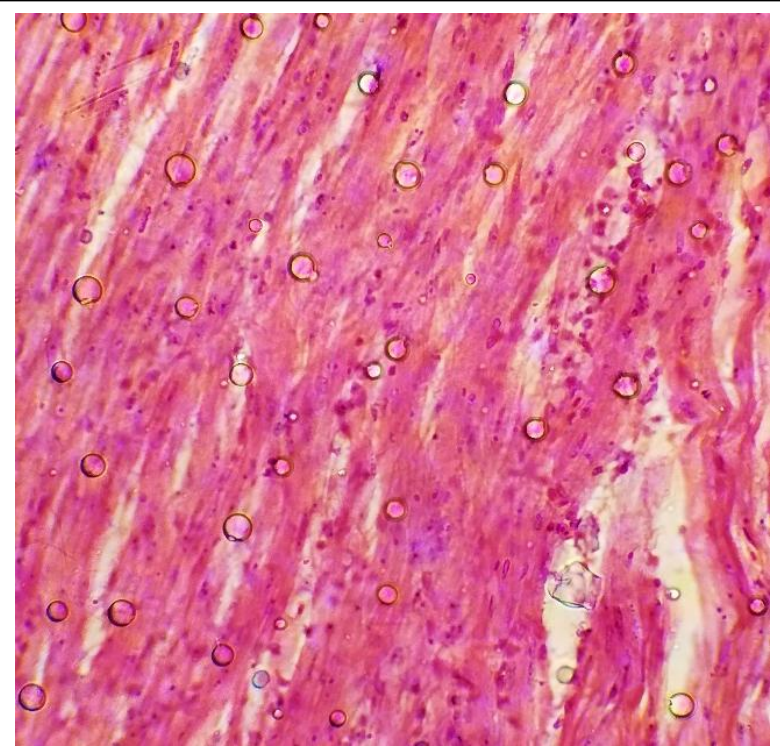

Puc. 20. Миокард: зернистая дистрофия, серозный отек стромы (окраска гематоксилином и эозином × 400)

При изучении патоморфологических изменений трупов кур-несушек, павших и вынужденно убитых вследствие инвазии нематодами Ascaridia galli, получены данные, свидетельствующие о комплексном патогенном воздействии аскаридий на организм птицы - непосредственном механическом повреждении структур слизистой оболочки кишечной стенки, токсическом влиянии продуктов жизнедеятельности паразитов и аллергической перестройки организма. У всех больных птиц выявлялись характерные патогномоничные изменения в органах пищеварительной, выделительной, репродуктивной и сердечно-сосудистой систем. В кишечнике куриц обнаруживались острые воспалительные процессы серозно-катарального и катаральногеморрагического характера, локализующиеся преимущественно в месте локализации паразитов - двенадцатиперстной и тощей кишках, сопровождающиеся геморрагическим диатезом и образованием эрозий в сочетании с развитием полной или частичной обтурации просвета аскаридиями, а также острый серозный панкреатит и выраженные дегенеративные процессы в печени, характеризующие состояние общей интоксикации и глубокие метаболические нарушения. К данной группе патологических процессов также можно отнести обнаруженные у всех птиц дистрофические процессы в почках и миокарде, которые способствовали развитию общего венозного застоя и снижению неспецифической резистентности организма птицы, в результате чего происходит осложнение инвазии воспалительными процессами органов репродуктивной системы, имеющими преимущественно катарально-геморрагический характер, чаще острое или подострое течение $[10,11]$. Аллергические процессы, развивающиеся на фоне тяжелой антигенной и токсической нагрузки, проявляются в виде плазматического пропитывания стенок сосудов преимущественно микроциркуляторного русла и наиболее выражены в клубочковом аппарате почек, обуславливая развитие мембранозного гломерулита. Для проведения дифференциальной диагностики в лабораторию отправлялся патолого-анатомический материал - фрагмент кишечника, кусочки легких, селезенки, печени, почек и поджелудочной железы, инфекция была исключена во всех случаях, что также подтверждает причину развития тяжелых воспалительных процессов в репродуктивных органах, которыми являются глубокие нарушения метаболизма, влекущие снижение моторной функции яйцевода, регулируемой действием гормонов яичника, в результате чего развиваются застойные явления, осложняющиеся воспалением тканей, чему также способствует резкое снижение общего и местного иммунитета организма птицы [10, 11].

Заключение. Анализируя результаты исследований, можно сделать вывод, что ведущую роль в развитии патологических процессов при 
инвазии нематодами Ascaridia galli у кур играют глубокие воспалительно-некробиотические процессы, развивающиеся в стенке кишечника, обуславливающие развитие общей интоксикации, дегенеративные изменения паренхиматозных органов, нарушения метаболизма, аллергические реакции и снижение сопротивляемости организма птиц к неспецифической микрофлоре, что ведет к осложнению воспалительными процессами органов репродуктивной системы и в комплексе обуславливает развитие истощения, полиорганной недостаточности и летальный исход.

\section{Литература}

1. Влияние напольно-выгульного содержания на интенсивность инвазии кур / Л.Г. Войтенко, Е.И. Нижельская, С.В. Буров [и др.] // Вестник Мичуринского государственного аграрного университета. - 2019. - № 3. C. 88-92.

2. Изучение аскаридиоза у птиц и выявление аскаридий в пищевом курином яйце / В.И. Белоусов, А.А. Варенцова, С.Б. Базарбаев [и др.] // Ученые записки КГАВМ им. Н.Э. Баумана. - 2019. - Т. 391. - № 3. C. 35-39.

3. Федотов С.В., Федотов В.П. Профилактика болезней и биотехника репродукции кур в фермерских хозяйствах. - Барнаул: Издво АГАУ, 2007. - $136 \mathrm{c}$.

4. Лимаренко А.А., Дубров И.С. Патоморфология и диагностика болезней птиц. - М.: Колос, 2007. - 448 c.

5. Effects of Ascaridia galli Infection in Two Breeds of Broilers / K.H. Yusuf, O.J. Ajanusi, A.I. Lawal, L. Saidu, I.D. Jatau // International Journal of Poultry Science. - 2016. - № 2. P. 72-75.

6. Population dynamics of Ascaridia galli following single infection in young chickens I T. Ferdushy, L. Luna-Olivares, P. Nejsum, A. Roepstorff, S. Thamsborg, N. Kyvsgaard II Parasitology. - № 9 (140). - P. 1078-1084.

7. Гайсина Л.А. Патоморфологические изменения в почках до и после лечения их антигельминтиками при аскаридиозе кур // Ученые записки КГАВМ им. Н.Э. Баумана. 2010. - T. 201. - C. 196-201.
8. Гайсина Л.А. Сравнительная патоморфологическая оценка антгельминтной эффективности новой фосффорной соли пиперазина при аскаридиозе кур: дис. ... канд. ветеринар. наук. - Казань, 2004. - 207 с.

9. Федотов С.В. Клинические признаки и патологоанатомические изменения при овариосальпингите кур-несушек // Актуальные проблемы ветеринарного образования: мат-лы междунар. конф. - Барнаул, 1998. C. 255-256.

10. Семенихина Н.М., Жуков В.М. Способ коррекции органопатологий репродуктивной системы у кур-несушек // Вестник Алтайского государственного аграрного университета. - 2014. - № 4 - С. 87-90.

11. Вахрушева Т.И. Особенности патоморфрологических изменений органов и тканей у курнесушек при патологии репродуктивной системы // Вестник КрасГАУ. - 2015. - № 11. C. 198-206.

\section{Literatura}

1. Vliyanie napol'no-vygul'nogo soderzhaniya na intensivnost' invazii kur / L.G. Vojtenko, E.I. Nizhel'skaya, S.V. Burov [i dr.] // Vestnik Michurinskogo gosudarstvennogo agrarnogo universiteta. - 2019. - № 3. - S. 88-92.

2. Izuchenie askaridioza u ptic i vyyavlenie askaridij v pishchevom kurinom yajce / V.I. Belousov, A.A. Varencova, S.B. Bazarbaev [i dr.] // Uchenye zapiski KGAVM im. N.E. Baumana. 2019. - T. 391. - № 3. - S. 35-39.

3. Fedotov S.V., Fedotov V.P. Profilaktika boleznej i biotekhnika reprodukcii kur $v$ fermerskih hozyajstvah. - Barnaul: Izd-vo AGAU, 2007. $136 \mathrm{~s}$.

4. Limarenko A.A., Dubrov I.S. Patomorfologiya i diagnostika boleznej ptic. - M.: Kolos, 2007. $448 \mathrm{~s}$.

5. Effects of Ascaridia galli Infection in Two Breeds of Broilers / K.H. Yusuf, O.J. Ajanusi, A.I. Lawal, L. Saidu, I.D. Jatau // International Journal of Poultry Science. - 2016. - № 2. P. 72-75.

6. Population dynamics of Ascaridia galli following single infection in young chickens / T. Ferdushy, L. Luna-Olivares, P. Nejsum, A. Roepstorff, 
S. Thamsborg, N. Kyvsgaard // Parasitology. № 9 (140). - P. 1078-1084.

7. Gajsina L.A. Patomorfologicheskie izmeneniya $\checkmark$ pochkah do i posle lecheniya in antigel'mintikami pri askaridioze kur // Uchenye zapiski KGAVM im. N.E. Baumana. - 2010. T. 201. - S. 196-201.

8. Gajsina L.A. Sravnitel'naya patomorfologicheskaya ocenka antgel'mintnoj effektivnosti novoj fosfornoj soli piperazina pri askaridioze kur: dis. ... kand. veterinar. nauk. - Kazan', 2004. - 207 c.

9. Fedotov S.V. Klinicheskie priznaki i patologoanatomicheskie izmeneniya pri ovariosal'pin- gite kur-nesushek // Aktual'nye problemy veterinarnogo obrazovaniya: mat-ly mezhdunar. konf. - Barnaul, 1998. - S. 255-256.

10. Semenihina N.M., Zhukov V.M. Sposob korrekcii organopatologij reproduktivnoj sistemy u kur-nesushek // Vestnik Altajskogo gosudarstvennogo agrarnogo universiteta. 2014. - № 4 - S. 87-90.

11. Vahrusheva T.I. Osobennosti patomorfologicheskih izmenenij organov i tkanej u kurnesushek pri patologii reproduktivnoj sistemy // Vestnik KrasGAU. - 2015. - № 11. - S. 198206. 